\title{
Estudo Comparativo entre a Bupivacaína a 0,5\% e a Mistura Enantiomérica de Bupivacaína (S75-R25) a 0,5\% em Anestesia Peridural em Pacientes Submetidos a Cirurgia Ortopédica de Membros Inferiores
}

\section{Comparative Study of $0.5 \%$ Bupivacaine Versus $0.5 \%$ Bupivacaine Enantiomeric Mixture (S75-R25) in Epidural Anesthesia for Orthopedic Surgery}

Pedro Paulo Tanaka, TSA ${ }^{1}$; Ronie Oliveira de Souza ${ }^{2}$; Matheus Felipe de Oliveira Salvalaggio ${ }^{2}$; Maria Aparecida de Almeida Tanaka ${ }^{3}$

\section{RESUMO}

Tanaka PP, Souza RO, Salvallagio MFO, Tanaka MAA - Estudo Comparativo entre a Bupivacaína a 0,5\% e a Mistura Enantiomérica de Bupivacaína (S75-R25) a 0,5\% em Anestesia Peridural em Pacientes Submetidos a Cirurgia Ortopédica de Membros Inferiores

JUSTIFICATIVA E OBJETIVOS: Com a finalidade de encontrar uma droga mais segura que a bupivacaína, vários estudos em animais foram realizados com seus isômeros. Este estudo tem como objetivo avaliar a eficácia da mistura enantiomérica de bupivacaína (S75-R25) a 0,5\% comparada a bupivacaína a $0,5 \%$ na anestesia peridural em pacientes submetidos à cirurgia ortopédica de membros inferiores.

MÉTODO: Participaram deste estudo, aleatório e duplamente encoberto, 38 pacientes, com idades entre 17 e 69 anos, estado físico ASA I e II, submetidos à cirurgia ortopédica de membros inferiores, distribuídos em dois grupos: Grupo B, que recebeu $30 \mathrm{ml}$ de uma solução de bupivacaína a 0,5\%, e Grupo MEB, que recebeu $30 \mathrm{ml}$ de uma solução da mistura enantiomérica de bupivacaína (S75-R25) a 0,5\%. Foram investigadas as características motoras e sensoriais do bloqueio anestésico, bem como a incidência de efeitos colaterais.

RESULTADOS: Houve diferença significativa em relação ao peso no grupo MEB. Os parâmetros hemodinâmicos foram semelhantes entre os grupos. Não houve diferença significativa em relação ao tempo necessário para atingir a maior intensidade de bloqueio motor e a altura do bloqueio sensitivo. O tempo de regressão do bloqueio motor foi

\footnotetext{
* Recebido do (Received from) CET/SBA do Hospital de Clínicas da Universidade Federal do Paraná (UFPr), Curitiba, PR

1. Professor Adjunto da Disciplina de Anestesiologia da Universidade Federal do Paraná. Co-responsável CET/SBA do Hospital de Clínicas da UFPr

2. $M E_{2}$ CET/SBA do Hospital de Clínicas da UFPr

3. Anestesiologista do Hospital de Clínicas da UFPr

Endereço para correspondência (Correspondence to)

Dr. Pedro Paulo Tanaka

Rua Justiniano de Mello e Silva, 355

82530-150 Curitiba, $P R$

E-mail: tanaka@bsi.com.br
}

Apresentado (Submitted) em 19 de agosto de 2002

Aceito (Accepted) para publicação em 09 de outubro de 2002

(c) Sociedade Brasileira de Anestesiologia, 2003 semelhante entre os dois grupos. A intensidade do bloqueio motor na escala de Bromage 2 foi maior no grupo MEB.

CONCLUSÕES: Foram observados adequados bloqueios motor e sensitivo para a realização da cirurgia em ambos os grupos, com poucos efeitos colaterais, sugerindo que as soluções são seguras na anestesia peridural para cirurgia ortopédica.

Unitermos: ANESTÉSICOS, Local: bupivacaína, mistura enantiomérica de bupivacaína; TÉCNICAS ANESTÉSICAS, Regional: peridural

\section{SUMMARY}

Tanaka PP, Souza RO, Salvallagio MFO, Tanaka MAA- Comparative Study of $0.5 \%$ Bupivacaine Versus $0.5 \%$ Bupivacaine Enantiomeric Mixture (S75-R25) in Epidural Anesthesia for Orthopedic Surgery

BACKGROUND AND OBJECTIVES: With the objective of finding a safer drug than racemic bupivacaine, several animal studies were performed with its enantiomers. This study aimed at evaluating the efficacy of $0.5 \%$ bupivacaine enantiomeric mixture (S75-R25) as compared to $0.5 \%$ bupivacaine in lumbar epidural anesthesia for lower limb orthopedic surgery.

METHODS: Participated in this randomized double-blind study 38 adult patients, aged 17 to 69 years, physical status ASA I and II submitted to lower limb orthopedic surgery, who were distributed in two groups: Group B - $30 \mathrm{ml}$ of $0.5 \%$ bupivacaine and Group BEM - $30 \mathrm{ml}$ of $0.5 \%$ bupivacaine enantiomeric mixture (S75-R25). Sensory and motor block characteristics were investigated, in addition to the incidence of side effects.

RESULTS: There have been significant weight differences in group BEM. Hemodynamic parameters were similar in both groups. There were no differences in time to reach Bromage score and peak block height. Also time to total motor block regression was similar between groups. There has been a significant difference in Bromage 2 score between groups, which was higher in group $B E M$.

CONCLUSIONS: Adequate sensory and motor block for surgery was achieved in both groups with few side effects, suggesting that both solutions are safe in lumbar epidural anesthesia for orthopedic surgery.

Key Words: ANESTHETICS, Local: bupivacaine, enantiomeric mixture of bupivacaine; ANESTHETIC TECHNIQUES, Regional: epidural 


\section{INTRODUÇÃO}

D urante várias décadas, a bupivacaína tem sido usada com sucesso na anestesia peridural para procedimentos de longa duração, proporcionando excelente anestesia sensitiva. No entanto, alguns inesperados acidentes com o uso da bupivacaína estimularam a busca por alternativas mais seguras, no que diz respeito a complicações cardiovasculares, bem como toxicidade no sistema nervoso central (SNC) ${ }^{1}$.

A bupivacaína é constituída de uma mistura equimolar entre dois enantiômeros: $\mathrm{R}(+)$ e $\mathrm{S}(-)$ bupivacaína ${ }^{2}$. Partindo-se dos isômeros purificados da molécula do anestésico local, pode-se manipular a relação enantiomérica de um composto racêmico. Com este artifício, contribui-se para sua eficácia e diminuição de sua toxicidade potencial, com elevação do índice terapêutico ${ }^{3}$.

Este estudo teve por objetivo a comparação entre a mistura enantiomérica de bupivacaína (S75-R25) a 0,5\% e bupivacaína a $0,5 \%$, no espaço peridural, para procedimentos ortopédicos em membros inferiores.

\section{MÉTODO}

Após aprovação da Comissão de Ética em Pesquisa do Hospital de Clínicas da Universidade Federal do Paraná, participaram do estudo, aleatório e duplamente encoberto, 38 pacientes, com idades entre 17 e 69 anos, estado físico ASA I e II, submetidos à cirurgia ortopédica de membros inferiores. Foram excluídos pacientes portadores de neuropatia periférica, reação de hipersensibilidade à bupivacaína, septicemia, deformidades da coluna vertebral e hipovolemia não controlada.

Os pacientes foram distribuídos em dois grupos de acordo com o anestésico local administrado: grupo MEB - pacientes que receberam mistura enantiomérica de bupivacaína (S75-R25) a 0,5\%; e grupo B - pacientes que receberam bupivacaína a $0,5 \%$. Eles receberam a visita pré-anestésica na noite anterior à cirurgia, na qual foram avaliadas suas condições físicas e solicitadas as autorizações para participação no estudo. Na manhã seguinte, ao adentrar à sala de cirurgia, após anestesia local com $1 \mathrm{ml}$ de lidocaína a $1 \%$, os pacientes foram submetidos à punção venosa com cateter $16 \mathrm{G}$ ou 18G. A monitorização constou de eletrocardiografia, na derivação $D_{\|}$, medida da pressão arterial por método não-invasivo e oximetria de pulso.

A punção peridural (espaço $L_{3}-L_{4}$ ou $L_{4}-L_{5}$ ) foi realizada com o paciente na posição sentada, precedida por infiltração dos planos superficiais com lidocaína a $1 \%$ sem vasoconstritor. O espaço peridural foi identificado através da técnica de perda da resistência, seguida da injeção da dose teste contendo $3 \mathrm{ml}$ da solução anestésica adicionados a $15 \mu \mathrm{g}$ de adrenalina. A seguir, foram injetados os restantes $27 \mathrm{ml} \mathrm{em}$ intervalo não superior a 10 minutos com aspiração a cada $5 \mathrm{ml}$. Na sala cirúrgica, permitiu-se a administração de doses fracionadas de midazolam, por via venosa, para sedação.
Após o término da injeção do anestésico (momento 0), foram avaliados os seguintes parâmetros: pressão arterial sistólica e diastólica, freqüência cardíaca, nível máximo sensitivo (dermátomo atingido), instalação e duração do bloqueio motor pela escala de Bromage ${ }^{4}$ nos seguintes momentos: 0,5 , $10,15,20,30,45,60,90$, e a cada 30 minutos até a regressão do bloqueio motor. Foram anotadas todas as complicaçõese intercorrências havidas em todo o período de acompanhamento, assim definidas: Mediatas - abalos musculares, tinitus, sonolência, agitação psicomotora, disritmia cardíaca, convulsão, hipotensão arterial maior que $30 \%$ da pressão sistólica inicial, freqüência cardíaca menor que 50 bpm. Tardias (24 horas de pós-operatório), dor no local da injeção, inflamação no local da injeção, áreas de anestesia e deficit motor.

Para a comprovação dos objetivos levantados no trabalho foram utilizados os testes paramétrico $t$ de Student (peso, altura, pressão arterial e freqüência cardíaca) e os não-paramétricos Mann-Whitney (idade, nível sensitivo, instalação e duração do bloqueio motor), Qui-quadrado (sexo e escala de Bromage)e Exato de Fisher (estado físico). O nível de significância mínimo adotado foi de $5 \%(0,05)$.

\section{RESULTADOS}

Foram alocados 41 pacientes sendo que 3 pacientes ( 2 do grupo $B$ e 1 do grupo MEB) foram retirados do estudo em razão de falha completa do bloqueio peridural.

Não houve diferença estatisticamente significativa entre os dois grupos no que concerne à idade, altura, sexo e estado físico (Tabela I). Diferença demográfica significativa foi encontrada em relação ao peso dos pacientes.

Tabela I - Dados Demográficos

\begin{tabular}{lcc}
\hline & $\begin{array}{c}\text { Grupo MEB } \\
(\mathrm{n}=18)\end{array}$ & $\begin{array}{c}\text { Grupo B } \\
(\mathrm{n}=20)\end{array}$ \\
\hline Idade (anos) & & \\
$\quad$ Média \pm DP & $34,9 \pm 11,7$ & $31,6 \pm 13,5$ \\
Mínima e máxima & $17-55$ & $17-69$ \\
Peso (kg) * & & \\
$\quad$ Média \pm DP & $75,2 \pm 10,4$ & $67,6 \pm 8,7$ \\
$\quad$ Mínima e máxima & $56-102$ & $56-88$ \\
Altura (m) & & $1,67 \pm 0,08$ \\
Média \pm DP & $1,71 \pm 0,09$ & $1,45-1,80$ \\
Mínima e máxima & $1,50-1,88$ & \\
Sexo & & 13 \\
Masculino & 14 & 7 \\
Feminino & 4 & 16 \\
Estado físico & & 4 \\
ASA I & 13 & \\
ASA II & 5 &
\end{tabular}

* Houve diferença significativa entre os grupos ( $t$ de Student) 
Os parâmetros hemodinâmicos nos diversos momentos estão representados nas figuras 1, 2 e 3, não havendo diferença entre os grupos estudados.

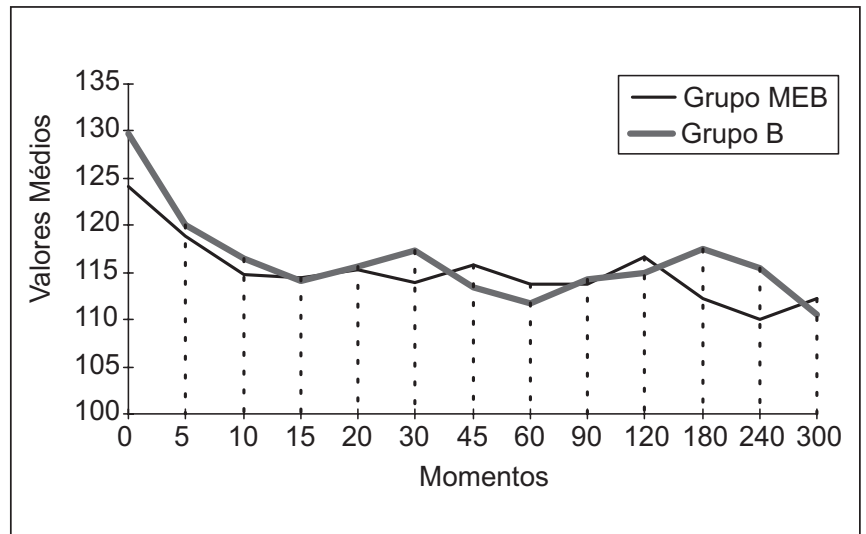

Figura 1 - Pressão Arterial Sistólica $(\mathrm{mmHg})$, nos Diferentes Momentos, nos Grupos em Estudo

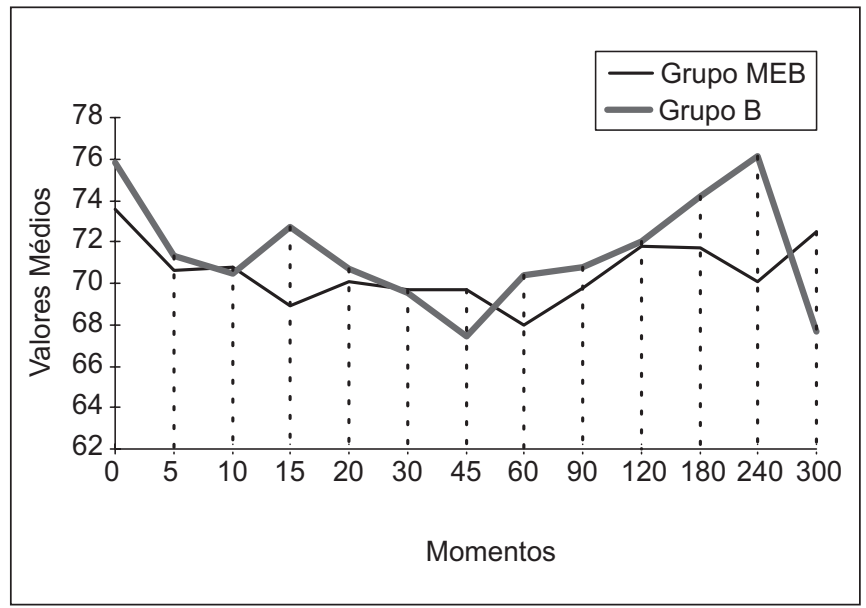

Figura 2 - Pressão Arterial Diastólica $(\mathrm{mmHg})$, nos Diferentes Momentos, nos Grupos em Estudo

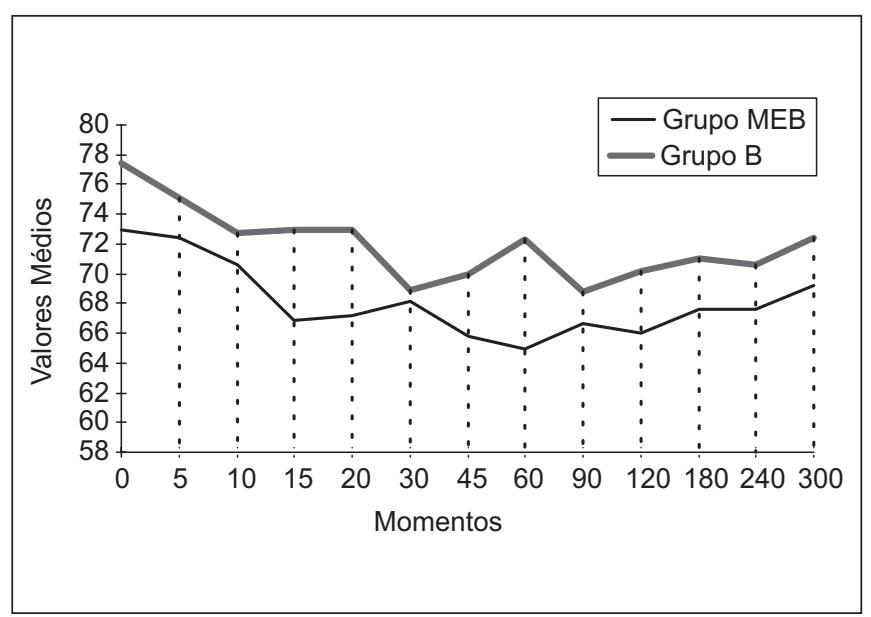

Figura 3 - Freqüência Cardíaca (bpm), nos Diferentes Momentos, nos Grupos em Estudo

Revista Brasileira de Anestesiologia

Vol. 53, № 3, Maio - Junho, 2003
Não houve diferença em relação ao tempo necessário para alcançar o máximo bloqueio motor e o nível sensitivo. Aduração do bloqueio motor foi semelhante entre os grupos estudados (Figura 4).

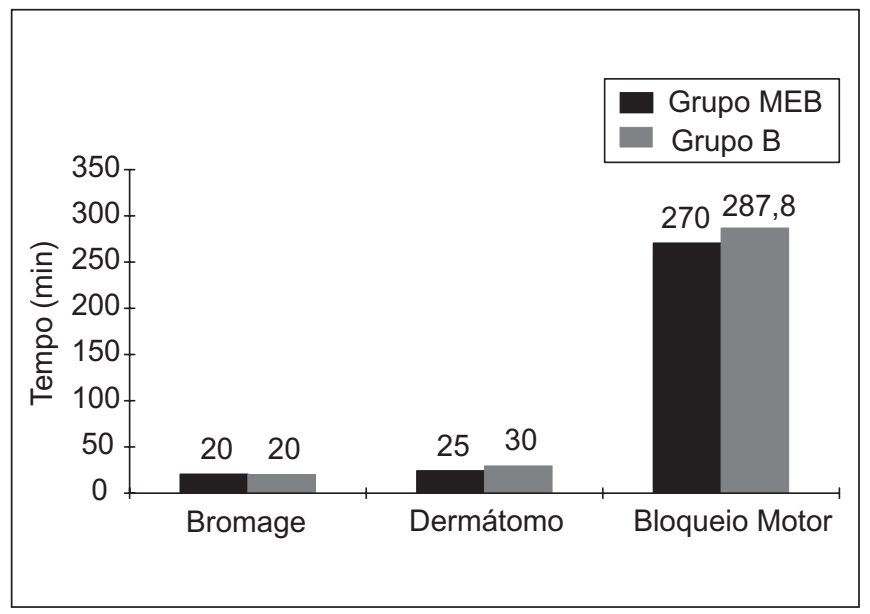

Figura 4 - Tempo Avaliado para Atingir Máximo Nível na Escala de Bromage e Dermátomo, Tempo de Regressão de Bloqueio Motor, nos Grupos em Estudo

Houve diferença significativa em relação à intensidade do bloqueio motor, sendo significativamente maior o número de pacientes do grupo MEB que apresentaram Bromage $2(p=$ 0,0284) (Figura 5).

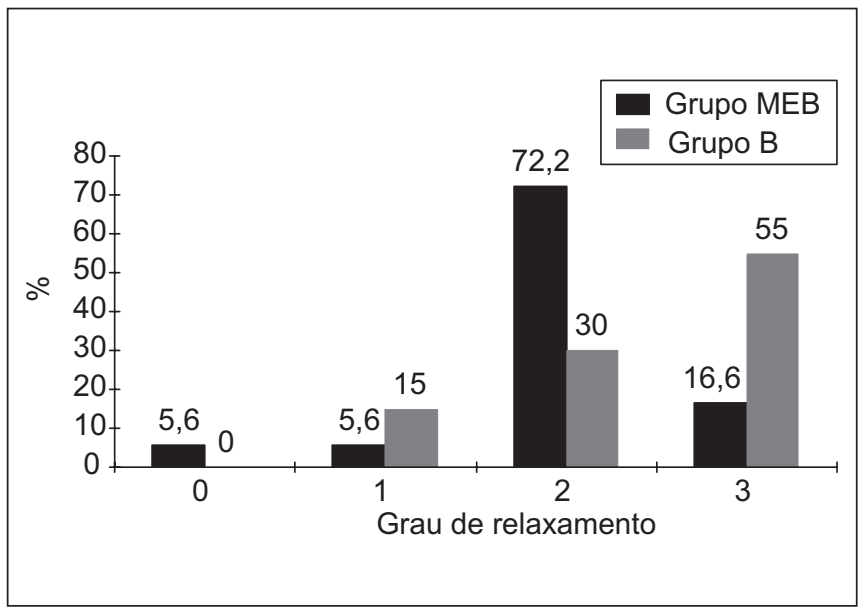

Figura 5 - Escala de Bromage nos Grupos em Estudo

Dois pacientes do grupo MEB apresentaram bradicardia durante a realização da punção peridural e outros dois durante o ato cirúrgico, sendo tratados com atropina. Dois pacientes em cada grupo receberam efedrina por apresentarem redução da pressão arterial. O número de falhas parciais foi igual entre os grupos (cinco pacientes). 


\section{DISCUSSÃO}

Neste estudo foi observada a homogeneidade demográfica entre os grupos, com exceção do peso, sendo este maior no grupo MEB. Embora este dado seja provavelmente casual em razão do tamanho da amostra, o peso como fator único apresenta pouca influência no bloqueio peridural. Seu valor recai sobre a segurança para aplicação de uma dose de anestésico local ${ }^{5}$.

$\mathrm{Na}$ presente pesquisa, foram padronizados outros fatores que poderiam influenciar o bloqueio, entre eles a concentração do anestésico local e volume a ser utilizado ${ }^{5}$. O volume de $30 \mathrm{ml}$ foi escolhido para que fossem registrados dados relativos à extensão do bloqueio vasomotor, visto não haver relatos na literatura do uso de doses maiores da mistura enantiomérica de bupivacaína. Na avaliação dos parâmetros hemodinâmicos, não houve diferença estatisticamente significativa nos diversos momentos estudados. Tanto a pressão arterial sistólica quanto a freqüência cardíaca demonstraram diminuição homogênea, como era de se esperar, pelo amplo bloqueio da cadeia simpática. Não obstante, somente dois pacientes em cada grupo necessitaram do uso de efedrina em doses que não foram superiores a $15 \mathrm{mg}$. Os resultados foram semelhantes a outros estudos envolvendo a solução enantiomérica de bupivacaína em anestesia peridural lombar ${ }^{6}$ ou torácica ${ }^{7}$.

A adição de adrenalina à solução de anestésico local promove vasoconstrição no local injetado, interferindo na velocidade de absorção da droga, fazendo com que ela permaneça mais tempo no local, em contato com as raízes nervosas ${ }^{5}$. Entretanto, outros autores demonstraram maior atividade vasoconstritora com isômero levógiro, fator considerado responsável pela longa duração do bloqueio sensorial ${ }^{8}$. No presente estudo estabelecemos que as soluções seriam administradas sem a adição de vasoconstritor após a dose teste, avaliando-se clinicamente o paciente durante a administração do anestésico local.

A literatura não apresenta nenhum estudo que contemple a mistura enantiomérica nas mesmas condições, o que nos leva a tecer considerações relativas a outros estudos que envolvam o enantiômero levógiro puro em situações semeIhantes ao nosso.

O tempo médio para atingir a máxima dispersão do bloqueio sensitivo foi de 25 minutos para o grupo MEB e de 30 minutos para o grupo $B$, resultado semelhante ao encontrado por outro autor ${ }^{9}$, em que foram relatados tempos médios de $25 \mathrm{mi}-$ nutos para soluções de levobupivacaína e bupivacaína racêmica a $0,5 \%$. O tempo para atingir o grau máximo de bloqueio motor, bem como para o retorno a zero na escala de Bromage foram, respectivamente, 20 e 270 minutos para o grupo MEB. Neste mesmo estudo realizado por Cox e col. ${ }^{9}$ os resultados foram semelhantes entre as soluções de levobupivacaína e bupivacaína racêmica a $0,5 \%$.

A diferença encontrada em relação ao grau de intensidade do bloqueio motor foi significativa, sendo maior o percentual de pacientes que apresentaram Bromage 2 no grupo MEB. Delfino e col., ${ }^{10}$ estudando o isômero levógiro puro a $0,5 \%$ em pacientes submetidos à cirurgia de varizes, também observaram o menor grau de bloqueio motor. Este fato corrobora a perda da potência miorrelaxante do isômero levógiro não somente da bupivacaína, mas também da ropivacaína ${ }^{11}$. Isto pode ser justificado pela presença exclusiva de amino-ácidos levógiros na formação dos canais de sódio no nódulo de Ranvier, acelerando a velocidade de ligação do anestésico local, em função de uma estereosseletividade decorrente de potencial modificação da afinidade e atividade intrínseca ${ }^{12}$.

Neste estudo foram observados adequados bloqueios motor e sensitivo para a realização da cirurgia em ambos os grupos, com poucos efeitos colaterais, sugerindo que as soluções são seguras na anestesia peridural para cirurgia ortopédica. Entretanto, devido à menor toxicidade da formulação enantiomérica de bupivacaína (S75-R25), ela representa uma alternativa segura em relação à bupivacaína racêmica.

\section{AGRADECIMENTOS}

Ao Laboratório Cristália pelo fornecimento das soluções anestésicas utilizadas neste estudo.

\section{Comparative Study of $0.5 \%$ Bupivacaine Versus $0.5 \%$ Bupivacaine Enantiomeric Mixture (S75-R25) in Epidural Anesthesia for Orthopedic Surgery}

Pedro Paulo Tanaka,TSA, M.D., Ronie Oliveira de Souza, M.D., Matheus Felipe de Oliveira Salvalaggio, M.D., Maria Aparecida de Almeida Tanaka, M.D.

\section{INTRODUCTION}

Bupivacaine has been successfully used for many decades in epidural anesthesia for long procedures, allowing excellent sensory anesthesia. However, some unexpected accidents with bupivacaine have led to the search for safer alternatives in terms of cardiovascular complications and central nervous system toxicity ${ }^{1}$.

Bupivacaine is an equimolar mixture of two enantiomers: $\mathrm{R}(+)$ and $\mathrm{S}(-)$ bupivacaine ${ }^{2}$. Starting from purified isomers of local anesthetic molecules it is possible to manipulate the enantiomeric ratio of a racemic compound. This trick contributes to its efficacy and decreases its potential toxicity increasing therapeutic index ${ }^{3}$.

Revista Brasileira de Anestesiologia Vol. 53, No 3, Maio - Junho, 2003 
This study aimed at comparing $0.5 \%$ bupivacaine enantiomeric mixture (S75-R25) versus $0.5 \%$ bupivacaine in the epidural space for lower limb orthopedic surgeries.

\section{METHODS}

After the Hospital de Clinicals, Universidade Federal, Paraná Ethics Committee approval, participated in this randomized double-blind study 38 patients aged 17 to 69 years, physical status ASA I and II, scheduled for lower limb orthopedic surgeries. Exclusion criteria were patients with peripheral neuropathy, hypersensitivity to bupivacaine, septicemia, spinal deformities and non-controlled hypovolemia. Patients were distributed in two groups according to the local anesthetic: Group BEM - 0.5\% bupivacaine enantiomeric mixture (S75-R25); and Group B - 0.5\% bupivacaine. Patients were pre-anesthetically evaluated the night before surgery when their physical conditions were checked and their consent was asked to participate in this study. The next morning, when entering the operating room after local anesthesia with $1 \mathrm{ml}$ of $1 \%$ lidocaine, patients were submitted to venous puncture with $16 \mathrm{G}$ or $18 \mathrm{G}$ catheters. Monitoring consisted of $E C G$ at $D_{\|}$lead, non-invasive blood pressure and pulse oximetry.

Epidural puncture $\left(L_{3}-L_{4}\right.$ or $L_{4}-L_{5}$ interspace) was performed in the sitting position, after superficial plan infiltration with $1 \%$ lidocaine without vasoconstrictor. Epidural space was identified by the loss of resistance technique, followed by test dose injection of $3 \mathrm{ml}$ of the anesthetic solution plus $15 \mu \mathrm{g}$ epinephrine. Then, remaining $27 \mathrm{ml}$ were injected in intervals not longer than 10 minutes and aspiration at every $5 \mathrm{ml}$.

Fractional intravenous midazolam doses were allowed in the operating room for sedation. At anesthetic injection completion (moment 0 ) the following parameters were evaluated: systolic and diastolic blood pressure, heart rate, upper sensory level (dermatome affected), motor block onset and duration by Bromage scale ${ }^{4}$ in the following moments: $0,5,10,15$, $20,30,45,60,90$, and at 30-minute intervals until motor block regression. All complications and intercurrences were recorded throughout the period and were defined as follows: Mediate - muscle shake, tinnitus, somnolence, psychomotor agitation, arrhythmia, seizure, arterial hypotension above $30 \%$ of baseline systolic pressure, heart rate below $50 \mathrm{bpm}$. Late (24 hours after surgery) - pain at injection site, inflammation at injection site, areas of anesthesia and motor deficit.

Student's $t$ test was used for parametric data (weight, height, blood pressure and heart rate) and Mann-Whitney test was used for non-parametric data (age, sensory level, motor block onset and duration). Chi-square was used for gender and Bromage scale and Fisher Exact test was used for physical status. Significance level was 5\% (0.05).

\section{RESULTS}

From 41 patients allocated, 3 patients (2 group B and 1 group $B E M)$ were excluded due to total epidural block failure.
There were no statistically significant differences between groups in age, height, gender and physical status (Table I). There have been significant differences in patients' weight.

Table I - Demographics Data

\begin{tabular}{lcc}
\hline & $\begin{array}{c}\text { Group BEM } \\
(\mathrm{n}=18)\end{array}$ & $\begin{array}{c}\text { Group B } \\
(\mathrm{n}=20)\end{array}$ \\
\hline Age (years) & $34.9 \pm 11.7$ & $31.6 \pm 13.5$ \\
Mean \pm SD & $17-55$ & $17-69$ \\
Lowest and highest & & \\
Weight (kg) * & $75.2 \pm 10.4$ & $67.6 \pm 8.7$ \\
Mean \pm SD & $56-102$ & $56-88$ \\
Lowest and highest & $1.71 \pm 0.09$ & $1.67 \pm 0.08$ \\
Height (m) & $1.50-1.88$ & $1.45-1.80$ \\
Mean \pm SD & & 13 \\
Lowest and highest & 14 & 7 \\
Gender & 4 & 16 \\
Male & & 4 \\
Female & 13 & \\
Physical status & 5 & \\
ASA I & & \\
ASA II & &
\end{tabular}

* There has been significant difference between groups (Student's $t$ )

Hemodynamic parameters in different moments are shown in figures 1, 2 and 3, without differences between groups.

There were no differences in time to reach highest motor and sensory block. Motor block duration was similar between groups (Figure 4). There have been significant differences in motor block intensity with a significantly higher number of group BEM patients presenting Bromage 2 $(p=0.0284)$ (Figure 5). Two group BEM patients presented bradycardia during epidural puncture and another two during surgery, being treated with atropine. Two patients in each group received ephedrine due to arterial hypotension. Partial failures were similar between groups (5 patients).

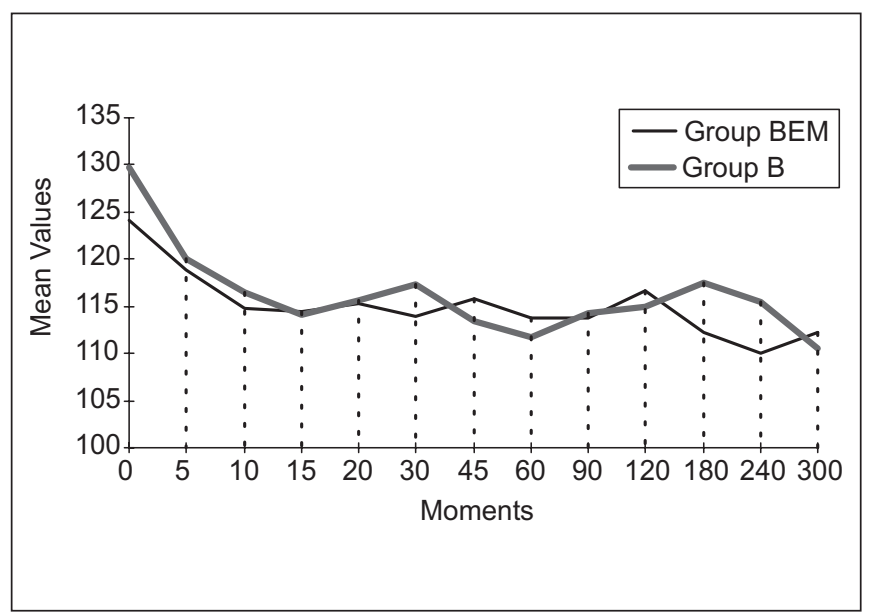

Figure 1 - Systolic Blood Pressure $(\mathrm{mmHg})$ in Different Moments in Both Groups 


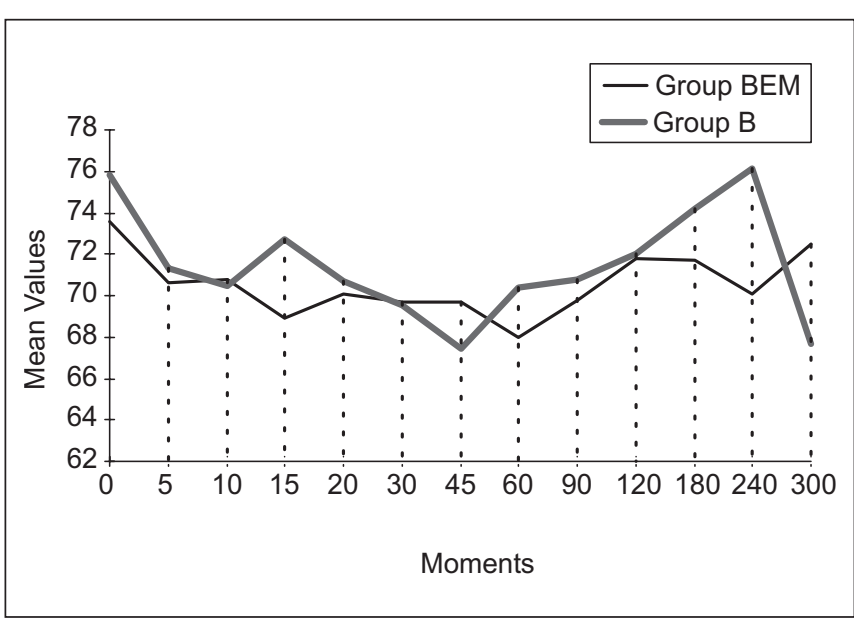

Figure 2 - Diastolic Blood Pressure ( $\mathrm{mmHg}$ ), in Different Moments in Both Groups

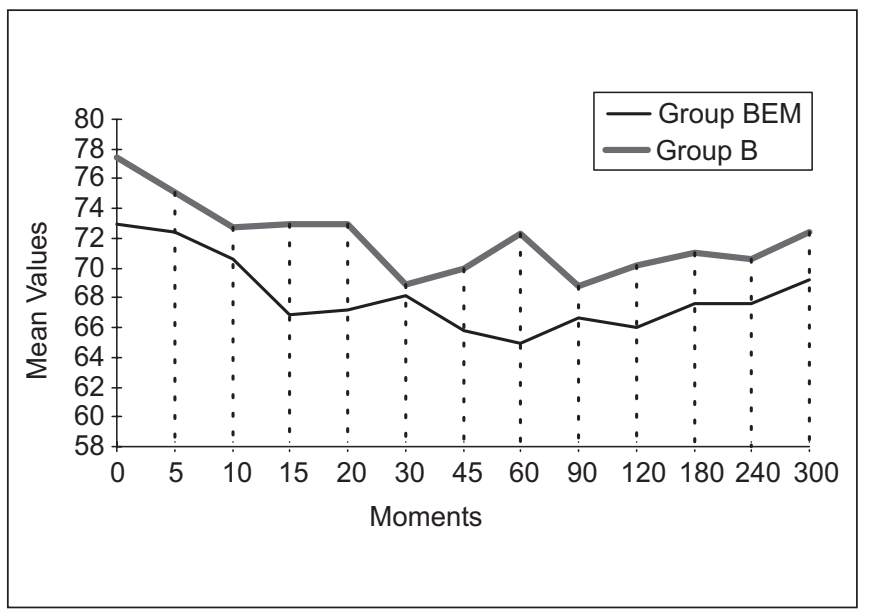

Figure 3 - Heart Rate (bpm) in Different Moments in Both Groups

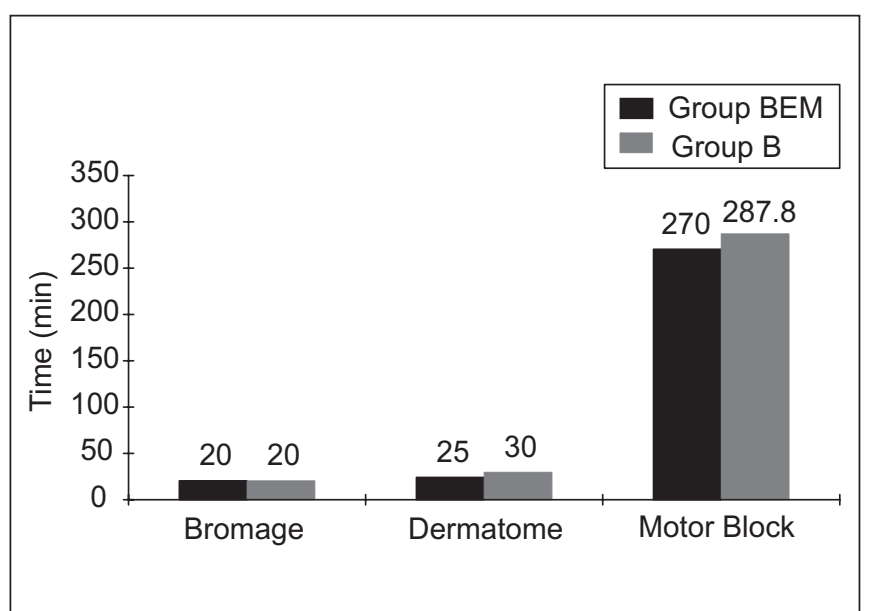

Figure 4 - Time to reach Highest Bromage Scale Level and Dermatome, Motor Block Regression

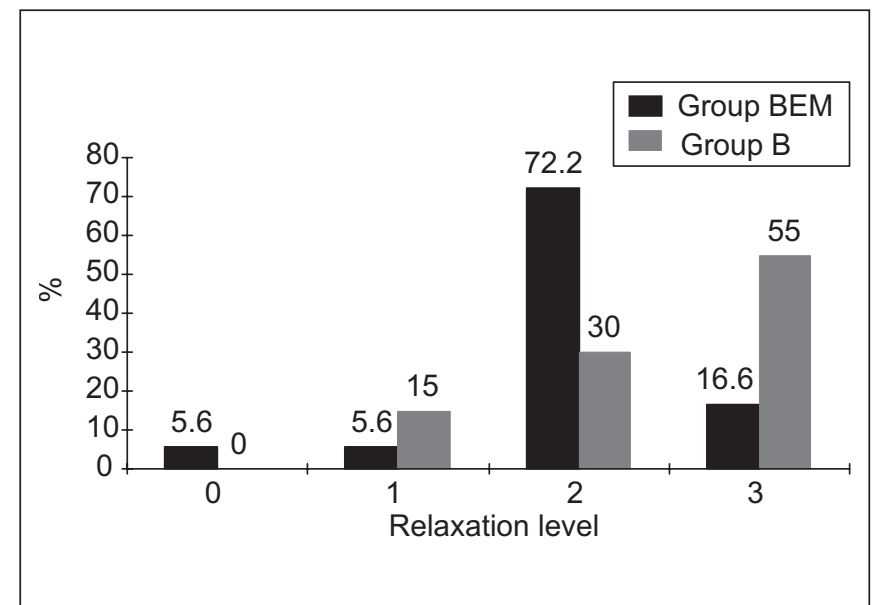

Figure 5 - Bromage Scale for Both Groups

\section{DISCUSSION}

There has been demographic homogeneity except for weight which was higher in group BEM. Although being possibly casual due to sample size, weight as a single factor has little influence in epidural block, being useful for the safety of a single application of local anesthetics ${ }^{5}$.

Other factors able to influence blockade were standardized in our study, among them local anesthetic concentration and volume ${ }^{5}$. The volume of $30 \mathrm{ml}$ was chosen so that data could be recorded to inform us about vasomotor block extension, since there are no reports in the literature about higher bupivacaine enantiomeric mixture doses. There were no statistically significant differences in hemodynamic parameters in all moments studied. Both systolic blood pressure and heart rate showed homogeneous decrease, as it was to be expected due to wide sympathetic chain blockade. In spite of this, only two patients in each group needed ephedrine in doses not higher than $15 \mathrm{mg}$. Results were similar to other studies involving bupivacaine enantiomeric mixture in lumbar ${ }^{6}$ or thoracic ${ }^{7}$ epidural anesthesia.

The association local anesthetics/epinephrine promotes vasoconstriction at the injection site interfering in drug absorption rate, allowing it to remain longer in contact with nervous roots ${ }^{5}$. However, other authors have shown more vasoconstrictor activity with the levogyrous isomer, factor considered responsible for long sensory block duration ${ }^{8}$. We decided to administer solutions without vasoconstrictor after the test dose, clinically evaluating patients during local anesthetic administration.

There are no studies in the literature involving the enantiomeric mixture in the same conditions, what leads us to consider further studies involving pure levogyrous enantiomer in similar situations to this study.

Mean time to reach maximum sensory block spread was 25 minutes for group BEM and 30 minutes for group $B$, being similar to other findings ${ }^{9}$ where mean times of 25 minutes for levobupivacaine and $0.5 \%$ racemic bupivacaine were re-

Revista Brasileira de Anestesiologia Vol. 53, No 3, Maio - Junho, 2003 
ported. Times to reach upper sensory block level and to return to zero in Bromage scale were 20 and 270 minutes, respectively, for group BEM. In a similar study by Cox et al. ${ }^{9}$, results were similar for levobupivacaine and $0.5 \%$ racemic bupivacaine.

Differences in motor block intensity were significant with more group BEM patients presenting Bromage 2. Delfino et al. ${ }^{10}$, studying $0.5 \%$ pure levogyrous isomer in patients submitted to varicose vein surgeries have also observed lower motor block. This confirms the loss of myorelaxing power of the levogyrous isomer of both bupivacaine and ropivacaine 11. This may be justified by the exclusive presence of levogyrous aminoacids in sodium channels formation in Ranvier's nodule, accelerating local anesthetic binding rate as a function of stereoselectivity due to potential change in affinity and intrinsic activity ${ }^{12}$.

There has been adequate motor and sensory block in our study to perform surgery in both groups with few side-effects, suggesting that solutions are safe for epidural anesthesia for orthopedic surgeries. However, due to the lower toxicity of bupivacaine enantiomeric mixture (S75-R25), it is a safe alternative as compared to racemic bupivacaine.

\section{ACKNOWLEDGMENTS}

To Laboratorio Cristalia for supplying anesthetic solutions used in this study.

\section{REFERÊNCIAS - REFERENCES}

01. Simonetti MPB, Batista RA, Ferreira FMC - Estereoisomeria: a interface da tecnologia industrial de medicamentos e da racionalização terapêutica. Rev Bras Anestesiol, 1999;48: 390-399.

02. Vale N, Delfino J - Farmacologia dos Anestésicos Locais, em: Vale N, Delfino J - Anestesia Peridural: Atualização e Perspectiva, São Paulo, Editora Atheneu, 2000;41-64.

03. Simonetti MPB - Anestésicos Locais Espinhais Levógiros, em: Vale N, Delfino J - Anestesia Peridural: Atualização e Perspectiva, São Paulo, Editora Atheneu, 2000;81-92.

04. Bromage PR - A comparison of the hydrochloride and carbon dioxide salts of lidocaine and prilocaine in epidural analgesia. Acta Anaesthesiol Scand, 1965;16:619-622.

05. Gouveia MA, Labrunie G - Fatores que Influenciam o Bloqueio Peridural, em: Vale N, Delfino J - Anestesia Peridural: Atualização e Perspectiva, São Paulo, Editora Atheneu, 2000;117-126.

06. Gonçalves RF, Lauretti GR, Omais M et al - Estudo comparativo entre a bupivacaína racêmica e a bupivacaína com apenas $25 \%$ do enantiomêro (+) na anestesia por via peridural. Rev Bras Anestesiol, 2001;(Supl27):CBA018.
07. Borba DA, Araújo JH, Leão DG et al - Comparação clínica da mistura $75 \%$ do enantiomêro levógiro de $25 \%$ do enantiomêro dextrógiro da bupivacaína com a forma racêmica em anestesia peridural torácica. Rev Bras Anestesiol, 2001;(Supl27): CBA017.

08. Newton DJ, Burke D, Khan F et al - Skin blood flow changes in response to intradermal injection of bupivacaine and levobupivacaine, assessed by laser Doppler imaging. Reg Anesth Pain Med, 2000;25:626-631.

09. Cox CR, Faccenda KA, Gilhooly C et al - Extradural S (-) bupivacaine: comparison with racemic RS-bupivacaine. $\mathrm{Br} J$ Anaesth, 1998;80:289-293.

10. Delfino J, Vale NB, Magalhães EF - Comparação entre bupivacaína racêmica e levógira a 0,5\%. Estudo em anestesia peridural para cirurgia de varizes. Rev Bras Anestesiol, 1999;49:4-8.

11. Ganem EM, Vianna PTG, Takata IT et al - Peridural com ropivacaína a $1 \%$ : experiência com volume proporcional à estatura. Rev Bras Anestesiol, 1998;48:283-288.

12. Delfino J, Vale NB, Magalhães EF - Comparação entre bupivacaína racêmica e levógira a 0,5\%. Estudo em anestesia peridural para cirurgia de varizes. Rev Bras Anestesiol, 1999;49:297.

\section{RESUMEN}

Tanaka PP, Souza RO, Salvallagio MFO, Tanaka MAA - Estudio Comparativo entre la Bupivacaína a 0,5\% y la Mezcla Enantiomérica de Bupivacaína (S75-R25) a 0,5\% en Anestesia Peridural en Pacientes Sometidos a Cirugía Ortopédica de Miembros Inferiores

JUSTIFICATIVA Y OBJETIVOS: Con la finalidad de encontrar una droga más segura que la bupivacaína, varios estudios en animales fueron realizados con sus isómeros. Este estudio tiene como objetivo evaluar la eficacia de la mezcla enantiomérica de bupivacaína (S75-R25) a 0,5\% comparada a bupivacaína a $0,5 \%$ en la anestesia peridural en pacientes sometidos a cirugía ortopédica de miembros inferiores.

MÉTODO: Participaron de este estudio, aleatorio y duplamente encubierto, 38 pacientes, con edades entre 17 y 69 años, estado físico ASA I y II, sometidos a cirugía ortopédica de miembros inferiores, distribuidos en dos grupos: Grupo B que recibió $30 \mathrm{ml}$ de una solución de bupivacaína a 0,5\% e Grupo MEB que recibió $30 \mathrm{ml}$ de una solución de la mezcla enantiomérica de bupivacaína (S75-R25) a 0,5\%. Fueron investigadas las características motoras y sensoriales del bloqueo anestésico, bien como la incidencia de efectos colaterales.

RESULTADOS: Hubo diferencia significativa en relación al peso en el grupo MEB. Los parámetros hemodinámicos fueron semejantes entre los grupos. No hubo diferencia significativa en relación al tiempo necesario para llegar a la mayor intensidad de bloqueo motor y la altura del bloqueo sensitivo. EL tiempo de regresión del bloqueo motor fue semejante entre los dos grupos. La intensidad do bloqueo motor en la escala de Bromage 2 fue mayor en el grupo MEB.

CONCLUSIONES: Fue observado adecuado bloqueo motor $y$ sensitivo para la realización de la cirugía en ambos los grupos con pocos efectos colaterales, sugiriendo que las soluciones son seguras en la anestesia peridural para cirugía ortopédica. 